\title{
The low level of glucagon-like peptide-1 (glp-1) is a risk factor of type 2 diabetes mellitus
}

\author{
Agus Lastya, Made Ratna Saraswati and Ketut Suastika*
}

\begin{abstract}
Background: Glucagon like peptide-1 (GLP-1), an incretin hormone, regulates glucose metabolism by inducing insulin secretion and suppressing glucagon secretion. The aim of the study is to assess the levels of fasting and post-prandial GLP-1 and their risk for T2DM. A case control study was conducted at the diabetes clinic Sanglah Hospital Denpasar Bali, involving 40 subjects who were native Indonesian citizens and 18-70 years of age. Twenty subjects were allocated as the case group (subjects with T2DM) and 20 subjects were allocated as the control group (subjects with normal glucose tolerance [NGT]). Both fasting intact GLP-1 (FGLP-1) and 60 minutes post-75 gram glucose loading intact GLP-1 (1hGLP-1) levels were measured.

Results: Both fasting and post-prandial GLP-1 levels were significantly lower in subjects with T2DM than those with NGT ( $2.06 \pm 0.43$ vs. $2.87 \pm 0.67 \mathrm{pg} / \mathrm{L}, \mathrm{p}<0.01$; and $2.49 \pm 0.60$ vs. $3.42 \pm 0.85 \mathrm{pg} / \mathrm{L}, \mathrm{p}=0.02$; respectively). Low levels of FGLP-1 (OR, 13.5; $p=0.001)$ and $1 \mathrm{hGLP}-1(\mathrm{OR}, 5.667, \mathrm{p}=0.018)$, with no response after glucose loading ( $\triangle \mathrm{GLP}-1)$, were a significant risk for T2DM. According to the $\triangle G L P-1$, there was a tendency of decreasing response of GLP-1 after glucose loading among subjects with T2DM $(\Delta=0.43 \mathrm{pg} / \mathrm{L})$ compared to subjects with NGT $(\Delta=0.55 \mathrm{pg} / \mathrm{L})$.

Conclusion: From this study it can be concluded that levels of intact GLP-1 are an important risk factor for T2DM in the Indonesian population.
\end{abstract}

Keywords: Levels of GLP-1, Type 2 diabetes mellitus

\section{Background}

Type 2 diabetes mellitus (T2DM) is a metabolic disease. It is a result of a combination of genetic predisposition, lifestyle and environment that are considered to be involved in its pathogenesis. Recently it has been widely known that changes of behavior, ways of life and the environment are predominant risk factors for T2DM [1]. The prevalence of T2DM in young adults is around 2.8 percent in 2000 and it is projected that the number of patients will increase from 171 million people in 2000 to approximately 366 million in 2030 [2]. In Bali, the prevalence of diabetes in adults was at $5.9 \%$ as reported by Suastika et al. in 2011 [3].

The concept that gut endocrine stimulates pancreatic secretion was first hypothesized in 1902. It was considered a big leap in the understanding of incretins that function as a regulator of blood glucose through regulation of insulin

\footnotetext{
* Correspondence: ksuas@yahoo.com

Division of Endocrinology and Metabolism, Department of Internal Medicine, Faculty of Medicine, Udayana University-Sanglah Hospital, Kamboja Street,
} Dangin Puri Kangin, No 8, 80233, Denpasar, Bali, Indonesia and glucagon secretion [4]. Two gut hormones, glucagonlike peptide-1 (GLP-1) and glucose dependent insulinotropic polypeptide or gastric inhibitory polypeptide (GIP), have been shown to act as incretins. GLP-1 has been developed as the basis of therapy for patients with T2DM. It was reported that in Caucasian patients with T2DM the GLP-1 levels decreased compared to that in normal subjects [5]. The total GLP-1 levels in among non-diabetic Japanese and Caucasians turned out to be comparable, but the intact GLP-1 levels was much lower in Japanese compared to Caucasians [6].

In Indonesia, no data on GLP-1 levels are available both in normal subjects and subjects with T2DM. Thus, this study was conducted to assess the GLP-1 levels in fasting and after glucose loading states and the response of GLP-1 after glucose loading; and to prove that low GLP-1 levels was a risk factor of T2DM in the Indonesian population.

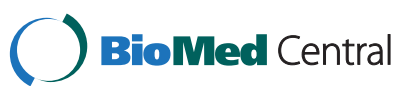

(c) 2014 Lastya et al.; licensee BioMed Central Ltd. This is an Open Access article distributed under the terms of the Creative Commons Attribution License (http://creativecommons.org/licenses/by/4.0), which permits unrestricted use, distribution, and reproduction in any medium, provided the original work is properly credited. The Creative Commons Public Domain Dedication waiver (http://creativecommons.org/publicdomain/zero/1.0/) applies to the data made available in this article, unless otherwise stated. 


\section{Methods}

A case-control study was conducted at the Diabetes Clinic Sanglah Hospital, Denpasar, Bali, Indonesia, during the period of February to April 2014. Twenty cases (subjects with T2DM) and 20 subjects with normal glucose tolerance (NGT), aged 18-70 years, were enrolled in the study as the control group. All subjects were native Indonesian citizens. The diagnosis of diabetes was confirmed based on the criteria of ADA (2014) [7]. The levels of intact GLP-1 were measured in fasting (FGLP-1, at least 8 hours) and 60 minutes post-loading standard 75 gram anhydrous glucose (1hGLP-1) states. The levels of plasma intact GLP-1 were measured by the EIA kit, Cat.No.: RSCYK 160R, Bio Vendor Research and Diagnostic Products. Low level of GLP-1 was confirmed if the level of FGLP-1 was $<2.21 \mathrm{pg} / \mathrm{L}$; 1 hGLP-1 was $<2.57 \mathrm{pg} / \mathrm{L}$; and the response or difference of fasting and post-prandial $(\Delta \mathrm{GLP}-1)$ was $<0.029 \mathrm{pg} / \mathrm{L}$. The values were determined by calculation of "mean-1SD" for each value (fasting, post-prandial and $\Delta$ ) in subject with NGT or control group. This study protocol was approved by the Research Ethics Committee Faculty of Medicine, Udayana University, Denpasar, before the study was conducted (registration no.790/UN.4.2/Litbang/ 2013). Written informed consent was obtained from all participants.

Statistical tests used to analyze the data in the study included a descriptive presentation, a Mann-Whitney test, cross-tab $(\chi 2$ test and prevalence risk or odds ratio [OR]), with significant value confirmed at $P<0.05$.

\section{Results}

The mean age of the subjects was $56.85 \pm 5.71$ years (case, $57.05 \pm 5.77$ years and control, $56.65 \pm 5.79$ years, respectively). Body mass index in subjects with T2DM was higher than subjects with NGT, 28.94 \pm 1.96 and $24.79 \pm 3.07$, respectively $(P<0.01)$. The mean of FGLP-1, 1hGLP-1, and $\triangle$ GLP-1 are seen in Table 1. Both FGLP-1 and 1hGLP-1 levels were lower significantly in subjects

Table 1 Levels of GLP-1 among subjects with T2DM and normoglycemia

\begin{tabular}{lccc}
\hline Variable & T2DM $(\mathbf{n}=\mathbf{2 0})$ & NGT $(\mathbf{n}=\mathbf{2 0})$ & $\boldsymbol{P}$ \\
\hline Fasting Plasma Sugar $(\mathrm{mg} / \mathrm{dl})$ & $194.70 \pm 10.50$ & $82.60 \pm 5.42$ & $<0.01$ \\
Prandial Plasma Sugar $(\mathrm{mg} / \mathrm{dl})$ & $315.35 \pm 26.25$ & $133.90 \pm 8.55$ & $<0.01$ \\
FGLP-1 $(\mathrm{pg} / \mathrm{L})$ & $2.06 \pm 0.43$ & $2.87 \pm 0.67$ & $<0.01$ \\
1hGLP-1 $(\mathrm{pg} / \mathrm{L})$ & $2.49 \pm 0.60$ & $3.42 \pm 0.85$ & 0.002 \\
$\Delta$ GLP-1 $(\mathrm{pg} / \mathrm{L})$ & $0.43 \pm 0.36$ & $0.55 \pm 0.52$ & 0.715 \\
\hline
\end{tabular}

T2DM, type 2 diabetes mellitus; NGT, normal glucose tolerance; FGLP-1, fasting GLP-1; 1 hGLP-1, 1 hour after glucose loading GLP-1; $\Delta \mathrm{GLP}-1$, responses of GLP-1 after loading.
Table 2 Risk of low FGLP-1, 1hGLP-1, and $\Delta$ GLP-1 levels for T2DM

\begin{tabular}{lcccc}
\hline & T2DM & NGT & OR (95\% CI) & P \\
\hline Fasting state & & & & \\
Low FGLP-1 & $12(60 \%)$ & $2(10 \%)$ & $13,5(2.434-74.867)$ & 0.001 \\
$\begin{array}{l}(<2.21 \mathrm{pg} / \mathrm{L}) \\
\text { Normal GLP-1 }\end{array}$ & $8(40 \%)$ & $18(90 \%)$ & & \\
$\begin{array}{l}(\geq 2.21 \mathrm{pg} / \mathrm{L}) \\
\text { Post-glucose loading state }\end{array}$ & & & \\
Low $1 \mathrm{hGLP}-1$ & $10(50 \%)$ & $3(15 \%)$ & $5.667(1.254-25.606)$ & 0.018 \\
$(<2.57 \mathrm{pg} / \mathrm{L})$ & & & & \\
$\begin{array}{l}\text { Normal } 1 \mathrm{hGLP}-1 \\
(\geq 2.57 \mathrm{pg} / \mathrm{L})\end{array}$ & $10(50 \%)$ & $17(85 \%)$ & & \\
$\begin{array}{l}\text { Difference }(\Delta) \\
\text { Low } \Delta \mathrm{GLP}-1\end{array}$ & $2(10 \%)$ & $2(10 \%)$ & $1.00(0.127-7.893)$ & 1.0 \\
$(<0.029 \mathrm{pg} / \mathrm{L})$ & & & & \\
$\begin{array}{l}\text { Normal } \Delta \mathrm{GLP}-1 \\
(\geq 0.029 \mathrm{pg} / \mathrm{L})\end{array}$ & $18(90 \%)$ & $18(90 \%)$ & & \\
\hline
\end{tabular}

T2DM, type 2 diabetes mellitus; NGT, normal glucose tolerance; FGLP-1, fasting GLP-1; 1hGLP-1, $1 \mathrm{~h}$ after glucose loading GLP-1; DGLP-1, responses of GLP-1 after loading.

with T2DM than those with NGT $(2.06 \pm 0.43$ vs. $2.87 \pm$ $0.67 \mathrm{pg} / \mathrm{L}, P<0.01$; and $2.49 \pm 0.60$ vs. $3.42 \pm 0.85 \mathrm{pg} / \mathrm{L}$, $P=0.02$; respectively).

Low levels of FGLP-1 and 1hGLP-1 were more frequently found in subjects with T2DM than in subjects with NGT $(60 \%$ vs. $10 \%, P=0.001$ and $50 \%$ vs. $15 \%, P=$ 0.018, respectively). Low levels of FGLP-1 (OR, 13.5; $P=0.001)$ and 1hGLP-1 (OR, 5.667, $P=0.018$ ) were significantly a risk factor for T2DM, but not for $\Delta$ GLP1 (Table 2). Although it has not been proven that $\triangle$ GLP-1 is a risk factor for T2DM, by looking at the response of GLP-1 after glucose loading, there seemed to be a tendency of decreasing response of GLP-1 among subjects with T2DM $(\Delta=0.43 \mathrm{pg} / \mathrm{L})$ compared to subjects with NGT $(\Delta=0.55 \mathrm{pg} / \mathrm{L})$ (Figure 1$)$.

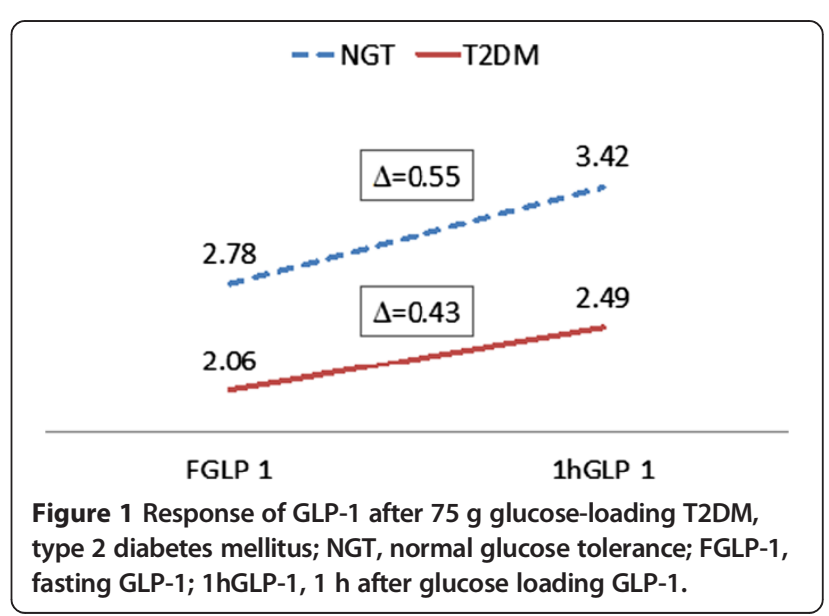




\section{Discussion}

This study revealed that the levels of GLP-1 in fasting and post-prandial states in subjects with T2DM were lower than in subjects with NGT (2.06 vs. $2.87 \mathrm{pg} / \mathrm{L}$ and 2.49 vs. $3.42 \mathrm{pg} / \mathrm{L}$, respectively). Velasquez-Mieyer et al. in 2008 reported that African-Americans exhibited lower GLP- $1_{\text {active }}$ levels at $15 \mathrm{~min}$ after OGTT than Caucasians (3.75 \pm 0.63 vs. $9.5 \pm 4.5 \mathrm{pmol} / \mathrm{L}, P=0.03)$ [8]. Levels of fasting GLP- $1_{\text {active }}$ in African-Americans was lower than in Caucasians $(3.31 \pm 1.14$ vs. $6.67 \pm 3.84 \mathrm{pmol} / \mathrm{L})$ but the difference was not statistically significant. As summarized by Seino et al. in 2010, the intact GLP-1 level was lower in Japanese than Caucasians [6]. Genetic or race background might influence the levels of GLP-1 since the levels widely vary among different races. In Japanese, fasting levels of total and intact GLP-1 were lower in patients with T2DM than the control group ( $15.5 \pm 1.7$ vs. $15.7 \pm 1.0$; and $0.2 \pm 0.1$ vs. $0.7 \pm 0.2 \mathrm{pM}$, respectively) [9]. In Chinese adults the levels of total fasting GLP-1, 2hGLP-1 decreased significantly in prediabetes (impaired fasting glycemia [IFG] and impaired glucose tolerance [IGT]) and T2DM compared to normal glucose tolerance (NGT) and isolated IFG or IGT [10]. A similar finding showed Caucasian subjects with T2DM had decreased GLP-1 levels compared to the control subjects $(23.8 \pm 3.17$ vs. $76.4 \pm$ $4.47 \mathrm{pg} / \mathrm{mL}, P<0.001)$ [11]. From the two review articles it can be summarized that low level of GLP-1 in T2DM is caused by impaired secretion of GLP-1 and accelerated metabolism of GLP-1. Low level or activity of GLP-1 in T2DM decrease an oral glucose dependent insulin secretion $[12,13]$.

Low levels of FGLP-1 (OR, 13.5) and 1hGLP-1 (OR, 5.667) seen in this study were significant risk factors for T2DM. Although the $\Delta$ GLP-1 was not a significant risk factor for T2DM, it revealed a trend of decreased response of intact GLP-1 after glucose loading among subjects with T2DM $(0.43 \mathrm{pg} / \mathrm{L})$ compared to subjects with NGT $(0.55 \mathrm{pg} / \mathrm{L})$. Two hours total GLP-1 increments ( $\triangle$ GLP-1) following OGTT reduced significantly in T2DM $(4.26 \pm 6.27 \mathrm{pmol} / \mathrm{L})$ group compared to NGT $(12.37 \pm 10.05 \mathrm{pmol} / \mathrm{L})$ and isolated IFG $(10.37 \pm 9.82 \mathrm{pmol} / \mathrm{L})$ or IGT $(9.79 \pm 10.50 \mathrm{pmol} / \mathrm{L})$ groups [10]. A similar result was also reported by Vilsboll et al. in 2003 that there was decreased GLP-1 responses after large meals in T2DM patients compared to healthy subjects [14].

Since there were differences in the type of GLP-1 (total or intact/active), method and unit GLP-1 measurement used in several different studies, there has been difficulty in comparing the absolute value between this study and other studies. However, it can be concluded that there was similarity in the findings that the levels of FGLP-1 and response after meal or glucose loading of
GLP-1 were reduced in subjects with T2DM compared to subjects with NGT.

\section{Conclusion}

Both FGLP-1 and 1hGLP-1 levels were lower in subjects with T2DM than in subjects with NGT. Low level of GLP-1 was an important risk factor of T2DM.

\section{Abbreviations}

1hGLP-1: 1 hour after glucose loading GLP-1; ADA: American Diabetes Association; FGLP-1: Fasting GLP-1; GLP-1: Glucagon-Like Peptide-1; IFG: Impaired fasting glucose; IGT: Impaired glucose tolerance; NGT: Normal glucose tolerance; T2DM: Type 2 diabetes mellitus; OR: Odd ratio.

\section{Competing interests}

The authors declare that they have no competing interests.

\section{Authors' contributions}

AL design the study and performed data analysis, interpreted the data, and drafted the manuscript. MRS participated in the design of the study and helped revise the final manuscript. KS participated in the design of the study and revised the final manuscript. All authors read and approved the final manuscript.

\section{Acknowledgment}

This study was supported in part by Indonesian Endocrinology Society Bali Chapter. The authors thank Prodia Laboratory for laboratory technical assistance.

Received: 17 September 2014 Accepted: 18 November 2014 Published: 26 November 2014

\section{References}

1. Suastika K: Treating Pre Diabetes, Implementing Diabetes Prevention Program Into Clinical Practise. In Kumpulan Naskah IImiah. Denpasar: Udayana University Press; 2008:84-87.

2. Wild S: Global prevalence of diabetes. Diabetes Care 2004, 27:1047-1053.

3. Suastika K, Dwipayana P, Saraswati I, Gotera W, Budhiarta A, Sutanegara I, Gunadi I, Nadha K, Wita W, Rina K, Santoso A, Matsumoto K, Kajiwara N, Taniguchi H: Prevalence of obesity, metabolic syndrome, impaired fasting glycemia, and diabetes in selected villages of Bali, Indonesia. JAFES 2011, 26:159-162.

4. Salehi A, Gylfe E: Glucose inhibits glucagon secretion by a direct effect on mouse pancreatic alpha cells. Diabetologia 2006, 50:370-379.

5. Vilsboll T, Agerso H, Krarup T, Holst JJ: Similar elimination rates of glucagon-like peptide- 1 in obese type 2 diabetic patients and healthy subjects. J Clin Endocrinol Met 2003, 88:220-224.

6. Seino Y, Fukushima M, Yabe D: GIP And GLP-1, the two incretin hormones: similarities and differences. J Diabetes Invest 2010, 1:8-23.

7. American Diabetes Association: Diagnosis and classification of diabetes. Diabetes Care 2014, 37(Suppl.1):S81-S90.

8. Vel'asquez-Mieyer PA, Cowan PA, P'erez-Faustinelli S, Nieto-Mart'inez R, Villegas-Barreto C, Tolley EA, Lustig RH, Alpert BS: Racial disparity in glucagon-like peptide 1 and inflammation markers among severely obese adolescents. Diabetes Care 2008, 31:770-775.

9. Yabe D: Little enhancement of meal-induced glucagon-like peptide 1 secretion in japanese: comparison of type 2 diabetes patients and healthy controls. J Diabetes Invest 2010, 1:56-59.

10. Zhang F, Tang X, Cao H, Lü Q, Li N, Liu Y, Zhang X, Zhang Y, Cao M, Wan J, An Z, Tong N: Impaired secretion of total glucagon-like peptide-1 in people with im-paired fasting glucose combined impaired glucose tolerance. Internat J Med Scien 2012, 9:574-581.

11. Legakis IN, Tzioras C, Phenekos C: Decreased glucagon-like peptide 1 fasting levels in type 2 diabetes. Diabetes Care 2003, 26:252.

12. Freeman JS: Role of the incretin pathway in the pathogenesis of type 2 diabetes mellitus. Cleve Clin J Med 2009, 76(Suppl 5):S12-S19. 
13. Nauck MA, Vardarli I, Deacon CF, Holst JJ, Meier Jj: Secretion of glucagon-like peptide-1 (glp-1) in type 2 diabetes: what is up, what is down? Diabetologia 2011, 54:10-18.

14. Vilsbøll T, Krarup T, Sonne J, Madsbad S, Vølund A, Juul AG, Holst JJ: Incretin secretion in relation to meal size and body weight in healthy subjects and people with type 1 and type 2 diabetes mellitus. J Clin Endocrinol Metab 2003, 88:2706-2713.

doi:10.1186/1756-0500-7-849

Cite this article as: Lastya et al:: The low level of glucagon-like peptide-1

(glp-1) is a risk factor of type 2 diabetes mellitus. BMC Research Notes

2014 7:849

\section{Submit your next manuscript to BioMed Central and take full advantage of:}

- Convenient online submission

- Thorough peer review

- No space constraints or color figure charges

- Immediate publication on acceptance

- Inclusion in PubMed, CAS, Scopus and Google Scholar

- Research which is freely available for redistribution 